\title{
Kanker in context
}

Citation for published version (APA):

Vooijs, M. (2012). Kanker in context. Océ Business Services. https://doi.org/10.26481/spe.20120621mv

Document status and date:

Published: 21/06/2012

DOI:

10.26481/spe.20120621mv

Document Version:

Publisher's PDF, also known as Version of record

\section{Please check the document version of this publication:}

- A submitted manuscript is the version of the article upon submission and before peer-review. There can be important differences between the submitted version and the official published version of record.

People interested in the research are advised to contact the author for the final version of the publication, or visit the DOI to the publisher's website.

- The final author version and the galley proof are versions of the publication after peer review.

- The final published version features the final layout of the paper including the volume, issue and page numbers.

Link to publication

\footnotetext{
General rights rights.

- You may freely distribute the URL identifying the publication in the public portal. please follow below link for the End User Agreement:

www.umlib.nl/taverne-license

Take down policy

If you believe that this document breaches copyright please contact us at:

repository@maastrichtuniversity.nl

providing details and we will investigate your claim.
}

Copyright and moral rights for the publications made accessible in the public portal are retained by the authors and/or other copyright owners and it is a condition of accessing publications that users recognise and abide by the legal requirements associated with these

- Users may download and print one copy of any publication from the public portal for the purpose of private study or research.

- You may not further distribute the material or use it for any profit-making activity or commercial gain

If the publication is distributed under the terms of Article $25 \mathrm{fa}$ of the Dutch Copyright Act, indicated by the "Taverne" license above, 


\section{Colophon}

Design \& print: OBS 8855 Océ Business Services, Maastricht

Afbeelding voorkant. Ebbinghaus illusie; Optisch bedrog waardoor het lijkt alsof de oranje cirkels verschillend van grootte zijn. Hier gebruikt ter illustratie dat context, de normale cellen

(blauw), een invloed hebben op kankercellen (oranje) in een tumor; oftewel dat de tumor

micro-omgeving bepalend is voor kankergroei en genezing.

ISBN: 000-000-000-0000

NUR: 000 system or made public without the prior written permission of the author or publisher.

\section{Kanker in Context}

Rede zoals uitgesproken ter aanvaarding van de leerstoel bijzonder hoogleraar in "Signalering in de tumor microomgeving" in de Faculty of Health Medicine and Life Sciences.

Maastricht, 21 juni 2012

Prof. dr Marc A.G.G. Vooijs 


\section{Kanker in context}

Dames en heren, familie, vrienden en collega's, meneer de rector en decaan; in de komende 40 minuten wil ik u laten kennis maken met mijn vakgebied: de biologie van kanker.

Ik wil beginnen met voor $\mathrm{u}$ de grote ontwikkelingen te schetsen in het kankeronderzoek van de afgelopen 10 jaar. Hier heeft een grote verschuiving plaatsgevonden in het denken. Deze nieuwe inzichten hebben consequenties voor de behandeling van kanker voor nu en in de toekomst voor velen onder ons. Tevens wil ik $u$ aan het eind kennis laten maken met hoe we deze informatie gebruiken binnen onze onderzoeksgroep op de afdeling Radiotherapie, en een blik werpen op de toekomst.

Het vakgebied van de Radiotherapie omvat de beeldvorming en behandeling van patiënten met kanker door middel van bestraling. Die behandeling is meestal gericht op genezing maar in sommige gevallen ook pijn-bestrijdend om onnodig lijden tot aan het einde te voorkomen. Naast radiotherapie is er ook chemotherapie; de behandeling van kanker met medicijnen en chirurgie het operatief verwijderen van kanker. Afhankelijk van de plaats en het type kanker omvat de behandeling vaak een combinatie van bovenstaande therapieën. Ongeveer de helft van alle kanker patiënten wordt met radiotherapie behandeld en $40 \%$ van patiënten die genezen van kanker zijn ooit met radiotherapie behandeld. Vergeleken met chirurgie en chemotherapie is radiotherapie ook verreweg de goedkoopste vorm van kanker therapie. Een belangrijke afweging in de behandeling van kanker is niet alleen het weghalen van de kanker maar ook het zoveel mogelijk sparen van het normale weefsel. De titel van deze lezing ter aanvaarding van mijn leerstoel is "Kanker in context". Context; de totale omgeving waardoor iets betekenis krijgt. De samenhang tussen de kankercellen en de normale cellen in het lichaam en hoe dit de ontstaanswijze en behandeling van kanker beïnvloedt.

Mijn vader was patholoog anatoom en onderzoeker; het liefst dat laatste geloof ik. Hij bestudeerde weefsels van kankerpatiënten. Dat deed hij door naar kankercellen te kijken onder de microscoop. Cellen afgenomen van patiënten met het vermoeden voor kanker. Regelmatig keek ik op het werk of thuis over zijn schouder mee. Ik zag gekleurde cellen, onzichtbaar voor het normale oog, vastgeplakt en uitgestrekt 
op een glaasje onder de microscoop onder verschillende vergrotingen. Ik zag kleine en grote cellen, ronde en gestrekte cellen en heel bizarre cellen; geen cel hetzelfde. Elk glaasje was anders. Elk glaasje was een andere patiënt. Mijn vader was op zoek naar kanker. Kanker in de baarmoeder. Samen maakten we soms opnames van de preparaten en drukte die af in mijn doka in de kelder van ons huis. We maakten enorme uitvergrotingen, details van kankercellen onherkenbaar en abstract voo mij, maar voor mijn vader onmiskenbaar kanker. Wat was hier gebeurd, wat lag ten grondslag aan die bizarre vormen?

Ik wist de keuze van mijn studie: medische biologie én dat ik onderzoek wilde doen. Ik stortte me op de moleculaire biologie en oncologie ofwel het vakgebied van kanker. Ik wil u niet teleurstellen in de eerste 3 minuten van mijn betoog: ik heb niet ontdekt waarom die cellen onder de microscoop van mijn vader er zo uitzagen; dat heeft iemand anders ontdekt en recent een Nobelprijs voor gekregen. Wat ik wel heb geleerd wil ik vandaag met $u$ delen.

Kanker is een ouderdomsziekte. Vanwege de dubbele vergrijzing (we worden steeds ouder en het aantal ouderen groeit) manifesteert dit zich in toenemende mate in onze samenleving. Het is doodsoorzaak nummer 1 in Nederland. In het onlangs verschenen rapport van van KWF kankerbestrijding "Kanker in Nederland tot 2020" luidt de kernconclusie dat hoewel er een daling in het risico van sterfte door kanker is als gevolg van een betere behandeling er een verwachte toename van $40 \%$ is in het aantal nieuwe kankerpatiënten naar 123 duizend per jaar in 2020.1

\section{Kanker: ziekte van genen}

Een gezwel, ook wel tumor, kan goedaardig of kwaadaardig zijn. Alleen bij kwaadaardige tumoren spreken we van kanker wat zich onderscheidt van goedaardig doordat de tumor kan uitzaaien. Uitgezaaide kanke is dodelijk. Genezing is dus met name gericht op het voorkomen van uitzaaiing en niet op het behandelen van uitgezaaide kanker. Om te begrijpen welke factoren belangrijk zijn voor kankergroei en uitzaaiing moeten we wat dieper in de biologie van de normale cel duiken. Immers kankercellen ontstaan uit normale cellen. Dus wat gaat er mis met een normale cel? Kanker is een ziekte van genen. Genen worden gecodeerd door het DNA, de code van het leven zoals we dat kennen op aarde; in elke cel van ons lichaam. Het DNA zit verpakt in chromosomen. Die zien eruit als een soort spiraalvormige zoutstengels ook wel DNA helix genoemd. Menselijke cellen hebben 23 paar, 2 van elk, dus totaal 46
De basis code van het menselijke DNA is nu geheel bekend en codeert voor ongeveer drieëntwintig duizend genen. Genen coderen op hun beurt weer voor eiwitten. Eiwitten zijn de werkers die bepalen of een cel rust, vermenigvuldigt, gaat bewegen, een signaal molecuul afgeeft of tot zelfdoding overgaat. Of je blauwe ogen hebt of je vroeg kaal wordt en aanleg hebt voor zwaarlijvigheid etc. Alle cel eigenschappen worden door genen bepaald. Kanker ontstaat als er fouten in deze genen ontstaan die zorgen dat er te weinig, te veel of een foutief eiwit wordt aangemaakt. Dus, foute genen maken foute eiwitten die leiden tot permanente verandering in het gedrag van cellen. Hoewel kanker een ziekte van genen is, is het maar in $5 \%$ van de gevallen een erfelijke ziekte van ouder naar kind. Dat wil zeggen dat het merendeel van de kanker niet erfelijk is en spontaan tijdens ons leven ontstaat.

Hoe ontstaan die veranderingen in genen? Fouten in ons DNA kunnen ontstaan op meerdere manieren. Er kunnen kleine fouten optreden ook wel mutaties genoemd. Er kunnen ook grote stukken DNA verloren gaan of extra bij komen. In alle gevallen kan het leiden tot te weinig, te veel of een veranderende functie van een of meerdere genen. Fouten in DNA kunnen spontaan ontstaan tijdens cel vermenigvuldiging wanneer de gen-code heel precies moeten worden gekopieerd alvorens gelijk verdeeld te kunnen worden over de dochtercellen. De eiwitten die hierbij betrokken zijn zijn uiterst gespecialiseerd maar vergissen zich wel eens. Als je bedenkt dat er 6 miljard bouwstenen in het DNA van elke cel zitten en dat dit bij elke celdeling moet worden gekopieerd en een volwassen mens uit ongeveer 1000 miljard cellen dan begrijp je dat er dagelijks nogal wat mis kan gaan. Gelukkig is er in normale cellen veel kwaliteitscontrole een soort keuringsdienst van waren die dit proces bewaken en instructies geven voor klein en groot onderhoud als er fouten worden aangetroffen. Dat hoeft niet altijd nadelig te zijn, integendeel mutaties in genen zijn ook de drijvende kracht achter evolutie: het ontstaan van nieuwe soorten en eigenschappen. Fouten in het DNA kunnen ook ontstaan door blootstelling aan radioactieve straling en chemicaliën. Denk aan de slachtoffers van de atoombom op Hiroshima en het reactor ongeluk in Tsjernobiel. Ook overmatige blootstelling aan UV straling door bijvoorbeeld 't zonnen leidt tot huidkanker. Blootstelling aan chemicaliën zoals asbest, sigarettenrook en alcohol verhogen de kans op long- en keelkanker. Virussen en bacteriën kunnen ook kanker veroorzaken en doen dat met name door de functie van eiwitten te blokkeren. Het DNA in de cel blijft onveranderd. 
Bekende voorbeelden zijn het Papilloma virus de veroorzaker van wratten die met formule $\mathrm{W}$ worden weggehaald, maar die ook kwaadaardige varianten kent die baarmoederhalskanker veroorzaken. Wat alle kankers gemeen hebben is dat de normale regelmechanismen die de integriteit van het DNA controleren, die celgroei, celdeling en beweging coördineren zelf zijn verstoord; zoals een trein die op hol slaat en uiteindelijk ontspoort omdat de noodrem niet werkt.

\section{Kerneigenschappen van kankercellen}

Wat zijn dan die eigenschappen die leiden tot verstoorde groei, to kanker? Ruim 100 jaar moleculair- en biomedisch onderzoek hebben geleid tot het vaststellen van 6 basiskenmerken van alle kankercellen Dit zijn de veranderingen die normale cellen moeten ondergaan om zicht tot een kwaadaardige kanker te ontwikkelen. Dat betreft dan zowe het verliezen van bescherm-mechanismen als het verkrijgen van nieuwe groei-bevorderende eigenschappen. Dus de rem, het gaspedaal en de koppeling die alles coördineert.

Boeverij, een bekende zoöloog die eerder al chromosomen had ontdekt als de dragers van erfelijke eigenschappen postuleerde in 1914 zijn theorie over kanker "Zur frage der Enstehhung Maligner Tumoren " of: over de oorzaak van het ontstaan van kwaadaardiger tumoren. ${ }^{2}$ Zijn conclusie, gebaseerd op de bestudering van zee-egel eieren was dat kanker werd veroorzaakt door een abnormale verdeling van chromosomen tijdens de celdeling. Kanker was dus een defect in de chromosomen: een celoverdraagbare eigenschap leidend tot ongebreidelde celdeling.

Daarnaast was het Boveri ook opgevallen dat kankercellen op normale cellen leken maar uiterlijke kenmerken of eigenschappen hadden verloren. Met andere woorden: Boveri postuleerde hier dat tumoren op meer primitieve cellen leken dan de normale cellen uit hetzelfde weefsel. Boveri speculeerde ook dat kwaadaardige tumoren uit goedaardige tumoren lijken te ontstaan: het proces van kankervorming is geleidelijk en bestaat uit verschillende opeenvolgende stappen. Het duurde bijna 80 jaar voordat Bert Vogelstein en collega's de relatie tussen genetische veranderingen in het DNA en de overgang van goedaardige poliepen in de darm naar invasive colorectale kanker publiceerde. Niet gehinderd door enige kennis van het bestaan van DNA (dat pas in 1953 Watson en Crick gepubliceerd werd) was Boveri zijn tijd ver dus vooruit en voorspelde wat ruim 100 jaar later samengevat werd door de kankeronderzoekers Hanahan en Weinberg in 2000 in het "Hallmarks of Cancer": de kerneigenschappen van kankercellen. ${ }^{3}$

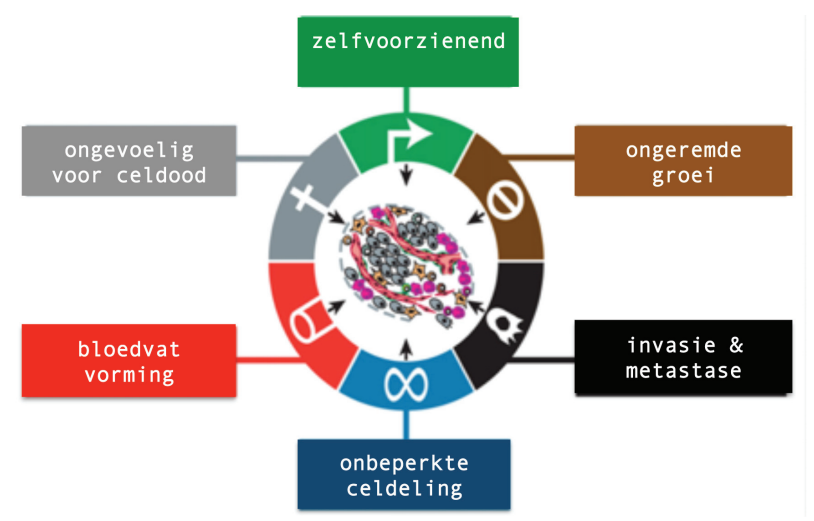

Lezen we met de klok mee dan zien we achtereenvolgens: zelfvoorziening in groei, ongevoeligheid voor remmende signalen, invasie en uitzaaiing, vermogen tot onbeperkte celdeling, aanmaak van bloedvaten (ook wel angiogenese genoemd) en ongevoeligheid voor celdood.

Die eigenschappen ontstaan doordat normale cellen spontaan of door de eerder genoemde risicofactoren, mutaties in genen ondergaan die deze processen reguleren. Dat is een geleidelijk proces waarbij normale cellen in de loop van tientallen jaren deze veranderingen stap voor stap ondergaan voordat er een uitgezaaide kanker is. Het is Darwiniaanse evolutie (dus survival of the fittest) in werking op de tijdschaal van een mensenleven. Het is maar goed dat er minstens zes eigenschappen nodig zijn om een kankercel te vormen anders zouden we allemaal kanker hebben. De kankercellen moeten dus telkens opnieuw een barrière overwinnen om een beetje sterker te worden waardoor ze beter overleven.

Er zijn ongeveer twee honderd verschillende soorten kanker bekend; dat betekent dat in alle 60 organen uit elk celtype in ons lichaam kanker kan ontstaan. Dat is op zich niet verwonderlijk aangezien elke cel hetzelfde DNA heeft en onderhevig is aan dezelfde controlemechanismen. De 5 meest voorkomende kankers in Nederland zijn borst-, darm-, huid-, long- en prostaatkanker. Nu de complete code van het menselijk DNA in kaart is gebracht is dezelfde technologie gebruikt om in kankercellen te kijken naar veranderingen in het DNA. Hieruit blijkt dat mutaties in een beperkt aantal van de 22.000 genen, ongeveer $1.5 \%$ (dat zijn 340 regelgenen) in kankercellen worden gevonden, die de eerder genoemde zes kernprocessen reguleren. ${ }^{4}$ Het aantal en soort mutaties verschilt per kanker; bijvoorbeeld in longkanker tussen rokers en niet-rokers. Vast staat dat veranderingen in het DNA de oorzaak zijn van kanker. 
Maar hoe komt het dat we anno 2012 de meeste veranderingen in het DNA van kankercellen kennen, beschikken over de meest geavanceerde medische technieken om kanker te zien, en medicijnen hebben ontwikkeld die kankercellen doden maar dat er nog heel veel kankerpatiënten overlijden?

Bij de ene patiënt slaat de therapie beter aan dan bij de andere; de ene overleeft de ander niet. De verklaring is omdat geen twee kankers hetzelfde zijn. Kanker is niet één ziekte maar twee honderd verschillende. Dat betekent dat elke patiënt anders is en dus ook anders behandeld zal moeten worden. Hoe komt dat al die kankers verschillen? De Londense arts Stephan Paget stelde al vast in 1889 dat borst kankers maar naar een beperkt aantal organen uitzaaiden. ${ }^{5}$ Zijn "seed en soil" hypothese postuleerde dat slechts enkele kankercellen (seeds) maar op een beperkt aantal plaatsen in het lichaam (soil) konden aanslaan en uitgroeien tot een nieuwe tumor.

\section{Kankers zijn heterogeen}

Ik heb $u$ verteld dat alle kankers dezelfde zes kenmerken delen, weliswaar in verschillende genen. We hebben impliciet aangenomen dat alle kankercellen in een tumor allemaal genetisch identiek zijn als een soort kloon. Maar is dat ook echt zo? Zelf ben ik opgeleid met dit evolutiemodel van kanker. Kankercellen ontstaan door een opeenvolging van veranderingen (mutaties). Ik heb u uitgelegd in welke signaalroutes die moeten plaatsvinden wil een tumor overleven. $\mathrm{Er}$ is dus telkens een selectie voor de tumorcel die het best overleeft. Uiteindelijk bestaat de tumor dan uit min of meer dezelfde kankercellen met allemaal dezelfde eigenschappen. In dit scenario is kanker behandeling en genezing gericht op het doden van alle kankercellen.

Pathologen en biologen weten al heel lang dat als je naar kankers kijkt en deze analyseert dat er heel veel verschillende soorten kankercellen in zitten. Diezelfde verschillen die ik ook door mijn vaders microscoop zag. Kankers zijn niet homogeen maar heterogeen: ze bestaan uit verschillende soorten kankercellen met verschillende eigenschappen. Sommige cellen delen, andere rusten sommige zijn meer gespecialiseerd terwijl andere meer primitief lijken. Uit experimentele studies halverwege vorige eeuw, toen DNA nog nauwelijks was ontdekt, bleek al dat slechts een beperkt aantal kankercellen in een tumor ook opnieuw een kanker vormen na transplantatie. Deze experimenten hebben geleid tot het concept van kanker stamcellen. Kanker stamcellen hebben net als normale stamcellen, die essentieel zijn voor de vorming en instandhouding van organen, de mogelijkheid tot ongelimiteerde zelfvernieuwing en de productie van meer gespecialiseerde celtypen. Bij kanker is de balans tussen zelfvernieuwing en celdood verstoort in het voordeel van celdeling waardoor de kanker groeit. De kanker stamcellen houden kanker groei in stand, als een soort bellenblaas machine. Je kunt de zeepbellen kapot prikken als je er last van hebt (de kanker behandeling van nu) maar zolang de machine aanstaat komen er steeds nieuwe bellen; je kunt dus beter de stekker eruit trekken. Het doden van kanker stamcellen zou in concept voldoende zijn om tot genezing te kunnen leiden. Terug naar Paget, die gelijk had: er zijn maar een beperkt aantal kankercellen die opnieuw ergens anders kunnen groeien. Hij beschreef ook dat die borstkankercellen maar naar een beperkt aantal organen toegaan. Dus de omgeving - de context- speelt ook een essentiële rol.

\section{Tumor micro-omgeving}

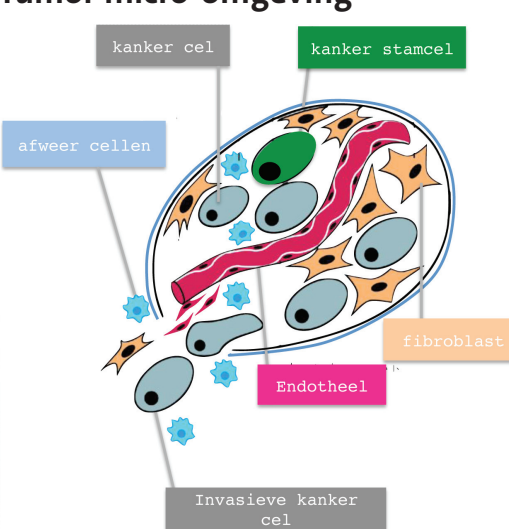

Er zijn nu harde experimentele bewijzen dat de normale lichaamscellen een belangrijke invloed uitoefenen op kankergroei en behandeling en visa versa. Het denken over kanker heeft zich van een reductionistische opvatting naar een meer holistische benadering verplaatst waarbij we de context dus de samenhang tussen kankercellen en normale cellen in het lichaam- dienen te betrekken in de ontstaanswijze, uitzaaiing en behandeling. We noemen dit ook wel de tumor micro-omgeving. ${ }^{6}$ De naam van mijn leerstoel signalering in de tumor micro-omgeving bestudeert de moleculaire processen die de tumorcellen en de context betreffen in het bijzonder de interactie tussen beide. We denken hierbij voornamelijk aan de bloedvatvormende endotheel cellen, bindweefsel cellen ook wel fibroblasten, en cellen van het immuun of afweer systeem. Tezamen noemen we dit de tumor micro omgeving.

In 1845 werd al door Virchow een verband gelegd tussen chronische irritatie door chemicaliën en ontsteking, als gevolg van infectie en 
abnormale celdeling. Bijvoorbeeld de bacterie Heliobacter Pylor veroorzaakt maagzweren die de kans op maagkanker vertienvoudigen. Patiënten met chronische darmontsteking of IBD hebben ook een verhoogde kans op darmkanker. Ook virussen zoals het humaan Papilloma virus kunnen zich jaren na infectie schuilhouden voordat ze aanzetten tot kwaadaardige groei. Sigarettenrook, bevat ongevee 60 kankerverwekkende stoffen die de luchtwegen en longen irriteren. Als roker heb je 20 x meer kans op longkanker dan een niet-roker, vier van de vijf longkankers is gerelateerd aan roken. De cijfers liegen er niet om. Maar wat is het verschil dan met het normale weefselherstel bijvoorbeeld na een snee met de kaasschaaf of na het stappen in een verroeste spijker? Hier is ook celdeling nodig om het kapotte weefsel te vervangen en te repareren. Dit proces wordt in gang gezet doo witte bloedcellen aangetrokken door signaal stoffen afgegeven uit het beschadigde gebied. Hierdoor vindt er bloedstolling, celdeling, aanmaak van bloedvaten en herordening van de weefsel structuur plaats. Bij kanker is dit proces verstoort: het proces van bloedvatvorming en celdeling blijft ongecontroleerd doorgaan: als een wond die maar niet wil genezen.

Is er ook bewijs voor het omgekeerde? Kunnen kankercellen ook ontstekingen veroorzaken? Het antwoord is ja. Kankercellen produceren factoren die cellen van het immuunsysteem aantrekken en hebben slimme manieren bedacht om onherkenbaar te blijven. Als een wolf in schaapskleren halen ze de afweercellen binnen om ze vervolgens in hun voordeel te gebruiken. Die afweercellen zijn diezelfde als nodig voor wond-herstel en produceren signaalstoffen waardoor tumorcellen vaker gaan delen en sneller bewegen. 10 jaar later in een update van de Hallmarks Paper lezen we dat het ontglippen van kanker aan het afweersysteem een zevende kenmerk is van vrijwel alle kankers. Experimenten in het laboratorium laten zien dat fibroblasten geïsoleerd uit kankers zich anders gedragen dan uit normale weefsels. Normale fibroblasten remmen namelijk de groei van kankercellen terwijl fibroblasten uit een kanker milieu juist het omgekeerde doen: zi stimuleren celdeling, beweeglijkheid en bloedvatvorming. Ze worden door de kankercellen geherprogrammeerd. Wie met pek omgaat wordt ermee besmet.

Het belang van bloedvatvorming is een van de zes kern kenmerken van het kanker proces. Het is niet verwonderlijk dat kankercellen-net als normale cellen- zuurstof en voedingsstoffen nodig hebben om te groeien. Door de snelle groei van tumoren kan uiteindelijk het normale bloedvatenstelsel hierin niet voorzien. Onder lage zuurstof condities, oftewel hypoxie, produceren kankercellen groeisignalen zoals vasculaire endotheel groeifactor (VEGF) die zorgen voor de vorming van nieuwe vertakkingen uit bestaande bloedvaten. Dit proces heet angiogenese (letterlijk vertaald bloedvorming). De afhankelijkheid van tumorcellen voor angiogenese is een functie van de afstand tot - of de werking vanhet bestaande vaten netwerk. Tumor angiogenese verschilt van normale angiogenese tijdens de ontwikkeling of gedurende wondherstel. Het vatenbed in kankers is onregelmatig en slecht van structuur: de vaten zijn lek waardoor er druk verlies ontstaat en het bloed stroomt niet gelijkmatig in één richting. ${ }^{8}$

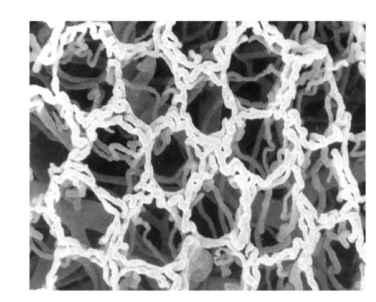

normaal

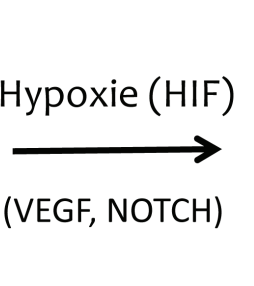

\section{)}

Een en ander heeft tot gevolg dat tumor angiogenese slechts tijdelijk de voorziening naar tumorcellen verbetert maar uiteindelijk toch weer zuurstofgebrek veroorzaakt. Uit bovenstaande is duidelijk dat het remmen van angiogenese een veel belovende strategie zou kunnen zijn om kankergroei te stoppen. Dat blijkt in de praktijk minder eenvoudig: daarover straks meer.

\section{Zuurstofgebrek (hypoxie): kenmerk van de meeste kankers}

Een achtste kenmerk van kanker is veranderingen in energiehuishouding, oftewel metabolisme. Normale cellen gebruiken zuurstof om suiker (glucose) te verbranden om energie te maken. Dat proces heet glycolyse. Groeiende tumoren zullen vaak te maken krijgen met zuurstofgebrek. Glucose-afbraak kan ook zonder zuurstof maar dat levert veel minder energie op. Om over voldoende energie te beschikken moeten kankers extra glucose opnemen uit de omgeving. Ze zijn suiker verslaafd. Afbraak van suiker in de afwezigheid van zuurstof leidt ook tot andere afbraakproducten, bijvoorbeeld melkzuur dat door de tumorcellen naar buiten wordt gepompt. Hetzelfde melkzuur dat spierpijn veroorzaakt 
na langdurige inspanning. Hypoxische tumorcellen verkeren dus in een zuur milieu. Die verzuring draagt bij aan het verhogen van de beweeglijkheid van cellen. Zuurstofgebrek, hypoxie is een algemeen kenmerk van de meeste kankers. De lucht die we inademen bevat ongeveer $21 \%$ zuurstof. De hoeveelheid zuurstof in weefsels is ongeveer tussen de $2-5 \%$. We spreken over hypoxie als er minder dan $1 \%$ zuursto is. Acuut zuurstofgebrek lijdt vaak tot cel afsterving, net als bij een infarct van de hersenen of het hart. Maar kankercellen zijn sluw, ze kunnen zich snel aanpassen. Ze activeren genen die ervoor zorgen dat de cellen beter overleven door het melkzuur uit de cel pompen en zorgen voor de extra opname en omzetting van suiker. Ook worden de kankercellen beweeglijker bij lage zuurstof en gaan zelf op zoek naar bloedvaten; ze zetten letterlijk alles in voor overleving. Veel van deze processen worden gedirigeerd door het eiwit met de toepasselijke naam hypoxie induceerbare factor oftewel HIF, niet te verwarren met HIV.

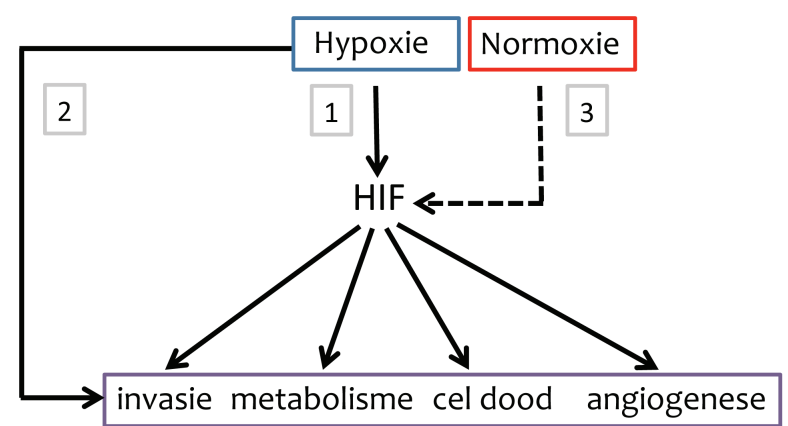

Deze zuurstofmeter in de cel komt voor in mensen muizen, vliegen en wormen. Kortom; sinds het ontstaan van zuurstof in ons heelal, ongeveer 2,5 miljard jaar geleden, hebben meercellige organismen manieren gevonden om zich aan te passen aan veranderingen in het zuurstofgehalte in hun omgeving. HIF is bijvoorbeeld belangrijk voor de productie van EPO: een hormoon verantwoordelijk voor de aanmaak van rode bloedcellen. Hoog in de bergen waar de lucht ijler is omdat er minder zuurstof is zorgt HIF ervoor dat er meer EPO komt waardoor we meer zuurstof kunnen opnemen en ons kunnen aanpassen. Maar hypoxische kankercellen activeren ook het HIF eiwit. Ik noemde eerde al het VEGF de factor die angiogenese aanstuurt. Enkele jaren geleden identificeerde mijn groep in Utrecht samen met Paul van Diest ook een eiwit gereguleerd door het HIF eiwit, Twist.9 Dat eiwit lijkt een belangrijke rol te spelen in invasie en uitzaaiing van kankercellen, weer een andere strategie die kankercellen gebruiken om zich aan te passen aan zuurstofgebrek, namelijk verkassen. Kankercellen vinden zelfs manieren om HIF te activeren zonder zuurstofgebrek (normoxie). Verder is HIF ook belangrijk voor de celdeling en celdood. Dit toont dat HIF een belangrijke schakel is in het ontstaan van kwaadaardige tumoren.

In tumoren ontstaat hypoxie naarmate de afstand van de tumorcellen tot de toevoerende bloedvaten groter wordt of als gevolg van slechtwerkende bloedvaten Dit heet ook wel chronische hypoxie en acute hypoxie. In deze patiëntenweefsels zijn de hypoxische kankercellen zichtbaar gemaakt in groen en de bloedvaten in het rood. We kunnen dat onder een microscoop zichtbaar maken. Er zijn duidelijk twee patronen. Groene zuurstof-arme cellen zichtbaar op afstand van een werkend bloedvat en groene cellen dichtbij een niet-werkend bloedvat. In kankers zien we vaak een combinatie van beide oorzaken; de onderliggende biologie is echter heel anders. De chronische hypoxische cellen zijn afhankelijk van HIF, de ander veel minder. De ene kanker is de andere niet en de bloed- en zuurstofvoorziening in kanker is niet statisch maar heel plastisch; het verandert continue en is hierdoor moeilijk grijpbaar. Hieronder een aantal voorbeelden van deze heterogeniteit in verschillende kankers van hetzelfde type. De biologische verschillen in tumor micro-omgeving zijn dramatisch toch worden deze drie patiënten op dit moment op dezelfde manier behandeld (met dank aan J. Bussink, H. Kaanders en B. van der Kogel, UMC Radboud).
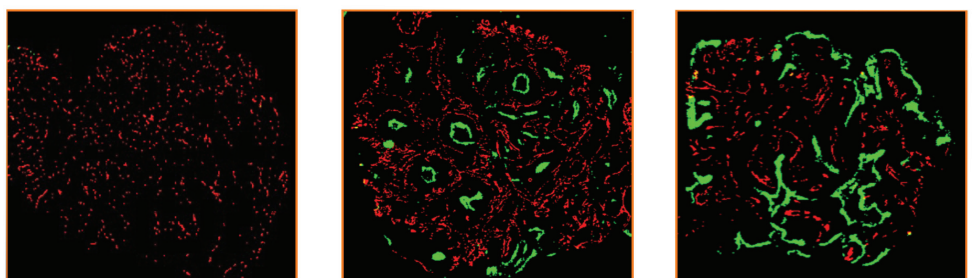

Wat betekent tumor-hypoxie voor patiënten? Leidt zuurstofgebrek dan ook tot meer agressieve kanker en een slechtere prognose? Ja, Hockel vond dat de zuurstofniveau's in baarmoederhalskanker veel lager waren dan die in het omringende normale baarmoeder weefsel. ${ }^{10}$ Het bleek dat in de groep waarbij de kanker operatief was verwijderd de patiënten met de meest zuurstofarme kanker minder lang overleefden (de blauwe curve). 

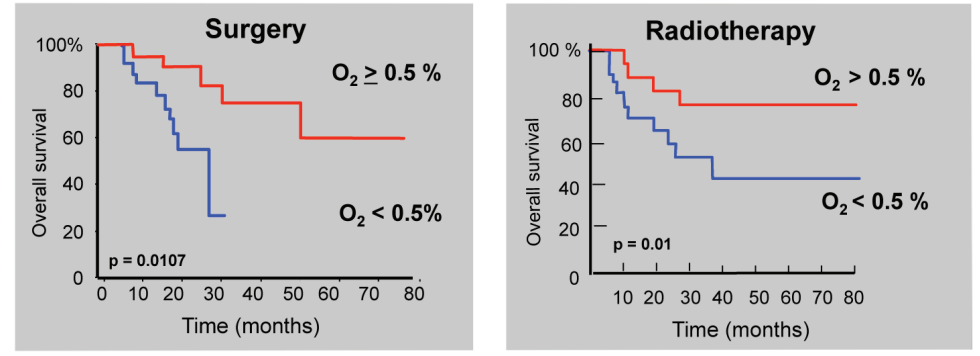

Tumor-hypoxie kan ook aangetoond worden door bijvoorbeeld naar de expressie van het HIF eiwit te kijken in afgenomen patiëntenmateriaal, hier in het bruin zicht baar in een hypoxisch gebied. Paul van Diest en collega's toonden aan dat borstkankers met veel HIF expressie een slechtere prognose hadden dan borstkanker met minder HIF." Omgekeerd betekent het ook dat patiënten waarbij geen HIF-expressie aangetoond kan worden deze misschien ook minder agressief behandeld kunnen worden omdat de kans op uitzaaiing klein is waardoor ze minder bijwerkingen hebben en ook de zorgkosten zullen dalen. Hypoxische kankers zijn niet alleen agressiever maar reageren ook minder goed op radiotherapie (de blauwe lijn)..$^{22}$ Dat komt omdat zuurstof cellen gevoeliger maakt voor de effecten van straling; ongeveer 3 maal zo gevoelig als in de afwezigheid van zuurstof. Dat betekent dat een drie maal zo hoge dosis straling nodig is om hypoxische tumorcellen te doden versus normale cellen.

Geneesmiddelen zijn ook minder effectief in hypoxische tumoren omdat ze vanwege de slechte doorbloeding moeilijk bij de kankercellen komen. Daarbij komt dat hypoxische cellen langzamer delen waardoor ze minder gevoelig zijn voor chemotherapie. Weergegeven in dit schema is de relatie tussen de afstand tot het bloedvat en de overleving van tumorcellen tijdens therapie. (aangepast van'3).

Patiënten met veel hypoxie in hun kanker hebben dan ook een slechtere prognose na therapie dan patiënten met minder hypoxie.De oncoloog radiotherapeut en chirurg hebben het niet makkelijk. Stel u eens voor: een tumor van 1 gram -ongeveer een centimeter doorsnede- dat zijn ongeveer $10^{9}$ cellen dat zijn 1 miljard cellen. Dat is een kleine tumor en door een arts tijdig te herkennen als deze aan de oppervlakte zit. Als we $99 \%$ van de tumorcellen doden betekent dat we nog steeds 10 miljoen cellen over hebben. Als dat dan ook nog een voor een deel de resistente hypoxische cellen zijn en mogelijk de kanker stamcellen begrijpt $u$ dat

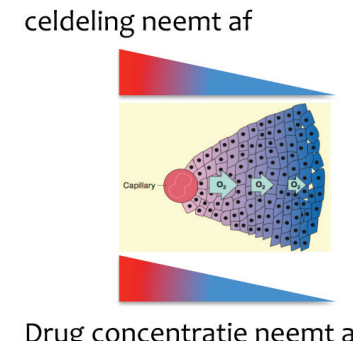

Drug concentratie neemt af

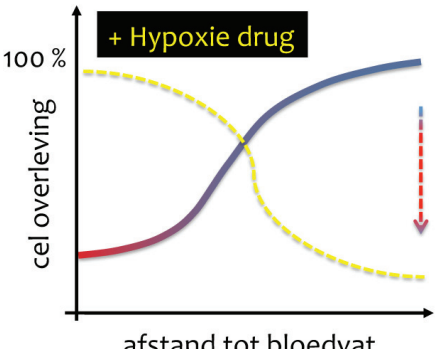

afstand tot bloedvat

met $99 \%$ succes het voor een dokter heel moeilijk is om een patiënt te genezen van kanker. In theorie kun je met voldoende straling elke cel doden, hypoxisch of niet. De beperking in radiotherapie is dan ook veelal de schade aan de normale weefsels en dus altijd een balans vinden tussen straling op de tumor maximaliseren terwijl de straling op het normale weefsel beperkt blijft, om complicaties op korte- en lange termijn te voorkomen. Therapieën gebaseerd op het selectief doden van hypoxische cellen zouden in theorie kankers dus gevoeliger voor radiotherapie kunnen maken en de schade aan het normale weefsel beperken. Het verschil tussen het voordeel op de tumor en het nadeel op het normale weefel heeft de therapeutische index, ik kom daar nog op terug.

\section{De tumor micro-omgeving in kankerbehandeling}

Als we nu in staat zouden zijn om de meest agressieve kankercellen -degene in het zuurstof-arme gebied- te identificeren en aan te pakken zou dit in theorie ook leiden tot een effectievere behandeling met radiotherapie of chemotherapie en betere vooruitzichten. Met effectiever bedoelen we dus meer celdood in de tumor en minder effecten op het normale weefsel. Er zijn meerdere strategieën denkbaar: het zuurstofrijker maken van tumoren vóór bestraling, het selectief doden van hypoxische cellen vóór therapie en het beschermen van het normale weefsel zodat de dosis op de tumor verhoogd kan worden. Ik wil voorbeelden geven van de eerste twee. Het is al 20 jaar bekend dat patiënten met hoofd-hals kanker die tijdens de radiotherapie behandeling stopten met roken langer leefden dan patiënten die gewoon door rookten. De achterliggende oorzaak is dat doordat rokers minder zuurstof opnemen in het bloed, hierdoor ook de kankers minder zuurstofrijk bloed bevatten en hierdoor ongevoeliger zijn voor bestraling. Momenteel loopt een grote studie bij de afdeling Radiotherapie in het UMC Radboud waarbij patiënten met hoofd-hals kanker gedurende 
de radiotherapie extra zuurstof toegediend krijgen in combinatie met een bloedvatverwijdend middel (de ARCON behandeling). De eerste resultaten lijken positief, patiënten die de ARCON behandeling krijgen (de rode curve) reageren beter op de therapie als ze een hypoxische tumor hadden. Voor patiënten met weinig tumor-hypoxie was er geen voordeel voor de ARCON behandeling ten opzichte van standaard therapie. ${ }^{14} \mathrm{Er}$ is ook een grote studie in Denemarken waarbij ze patiënten voor behandeling Nimerazole geven, een geneesmiddel dat selectief hypoxische cellen doodt.

De eerste resultaten laten zien dat patiënten met hypoxische kankers (de rode curve) hier voordeel van hebben en hun tumor minder snel terug komt. In Denemarken is dit nu onderdeel van standard care in de behandeling van hoofdhals kanker. ${ }^{15}$

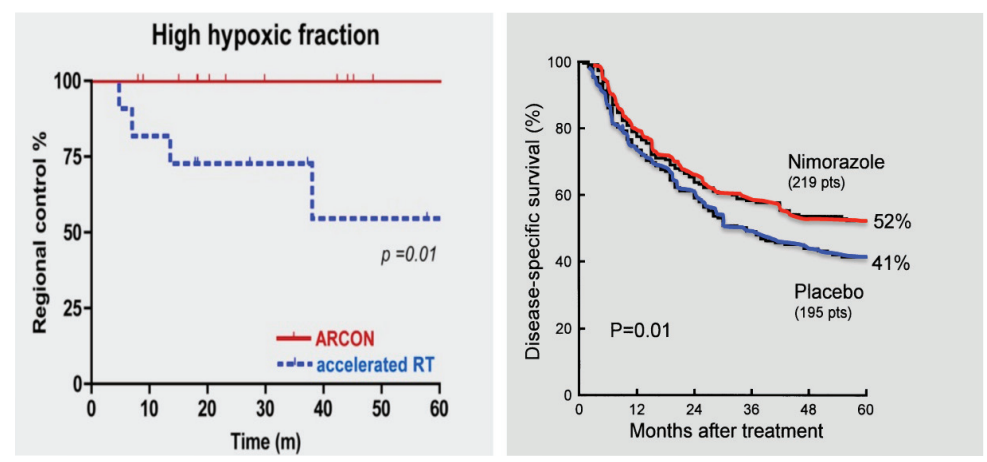

Er wordt hard gewerkt (ook in ons laboratorium) aan de ontwikkeling van gevoelige testen die aantonen of een kanker hypoxisch is of niet. Dat is niet eenvoudig omdat een klein stukje afgenomen tumorweefsel zeer waarschijnlijk niet representatief is. We zullen dus op zoek moeten gaan naar merkers, in het bloed of urine die het gedrag van de kanker voorspellen, die representatief zijn. Ook beeldvorming op basis van biologische karakteristieken van tumor en normaal weefsel tijdens het gehele behandelproces zal hierbij een cruciale rol spelen om de zuurstof arme gebieden in de patiënt tijdens de behandeling zichtbaar te maken. Ik geef $u$ hier dadelijk een voorbeeld van. Bovenstaande voorbeelden laten zien dat het opheffen van tumor hypoxie, therapeutische voordelen biedt. Lange termijn prognoses laten nog op zich wachten maar er is reden voor optimisme.
Ik heb $\mathrm{u}$ geprobeerd te overtuigen dat tumorgroei ook door normale cellen wordt beïnvloedt. Ik heb u ook verteld dat zuurstofgebrek in vrijwel alle kwaadaardige tumoren een rol speelt en leidt tot agressievere tumoren en een slechtere response op therapie. Tenslotte heb ik u verteld dat niet alle kankercellen hetzelfde zijn en dat het belangrijk is om te weten welke cellen we moeten doden voor genezing.

In het laatste gedeelte van mijn voordracht wil ik u wat voorbeelden geven uit het onderzoek binnen onze vakgroep en hoe we deze kennis willen gaan gebruiken in de opsporing en behandeling van kanker met radiotherapie.

\section{Wat doen we nou eigenlijk}

De essentie van datgene dat we in het laboratorium doen is te onderzoeken welke eigenschappen kankercellen gevoeliger maken voor bestraling en tegelijkertijd bestuderen hoe we het normale weefsel kunnen beschermen, de therapeutische index verhogen.

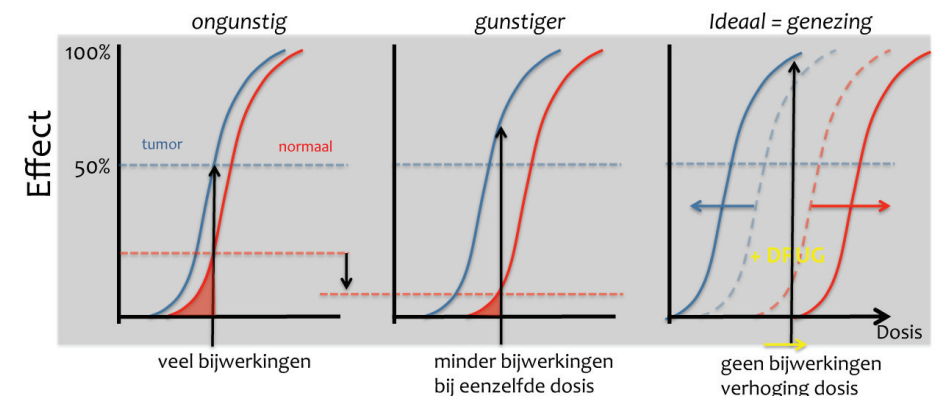

Als de tumor en het normale weefsel weinig verschillen in de gevoeligheid voor straling is dit ongunstig, Er zullen veel complicaties in het normale weefsel optreden (de rode driehoek) waardoor de dosis zodanig beperkt moet worden dat er veel tumorcellen overleven. Hoe verder deze curven uit elkaar liggen- hoe kleiner de rode driehoek- hoe gunstiger.

Ik hoop u duidelijk gemaakt te hebben dat door de biologie van kankercellen te bestuderen, in het bijzonder die van de therapieresistente hypoxische cellen, we geneesmiddelen zouden kunnen ontwikkelen specifiek gericht om die therapeutische index te vergroten. Hoe verder die curven uit elkaar liggen hoe effectiever de behandeling. 
Dit kan op twee manieren, enerzijds door de tumorcellen gevoeliger te maken voor bestraling en anderzijds door normale cellen beter te beschermen; idealiter een combinatie van beide.

Deze curven verschillen voor elk weefsel en zijn afhankelijk van meerdere factoren onder andere de delingssnelheid, de capaciteit tot schade reparatie en de mate van hypoxie. Aangezien radiotherapie een lokale therapie is dat voordelig voor het normale weefsel ten opzichte van systemische therapieën zoals chemotherapie. In combinatie met beeldvorming kunnen we steeds nauwkeuriger biologische eigenschappen in beeld brengen zoals hypoxie, glucose-opname zodat we de meest resistente gebieden agressiever kunnen behandelen: een hogere dosis geven terwijl de rest minder krijgt. Dat concept heet dose-painting. Afhankelijk van de biologische kenmerken wordt de dosis aangepast binnen een-en-dezelfde tumor. Hierdoor wordt de therapeutische index verhoogd.

\section{Functionele beeldvorming in kanker}

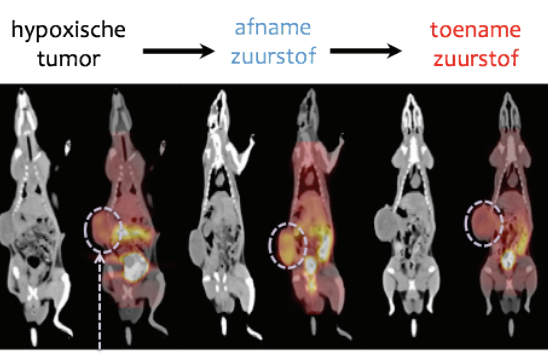

tumor opname probe afgifte probe

In het lab hebben we de aatste jaren modellen ontwikkeld waarmee we in proefdieren zuurstof arme gebieden in tumoren zichtbaar kunnen maken. ${ }^{16}$ In dit voorbeeld zien we de opname van een merker voor hypoxische cellen in een rat met kanker. De opname verminderd als we de dieren extra zuurstof geven en vermeerderd als we de dieren verlaagd zuurstof laten ademen. Deze modellen illustreren de kracht van beeldvorming en maken het mogelijk om nauwkeurig het effect van hypoxie op radiotherapie en vice versa te volgen. We hebben inmiddels deze zuurstof sensor ook in patiënten getest met long kanker en inmiddels ook in hoofd hals kanker. ${ }^{17}$

We proberen ook biologische parameters zoals glucose-opname en zuurgraad te bestuderen in de relatie met hypoxie. We willen weten welke merker het best voorspelt welke cellen resistent zijn en de hoogste dosis moeten krijgen. Immers we willen de therapie resistente cellen verwijderen vóór aanvang van de therapie! In samenwerking met de groep van Frank Verhaegen in Maastro Clinic hebben we de beschikking over apparatuur om precieze bestralingen zoals in de mens nu ook uit te voeren in de muis. Dit is een unieke opstelling waarmee we met grotere waarschijnlijkheid het succes van nieuwe experimentele behandelingen kunnen voorspellen alvorens naar een patiënt te gaan. Momenteel zijn we het dose-painting in combinatie met hypoxie merkers aan het testen in patiënten. Dit is dus een mooi voorbeeld van geïndividualiseerde therapie, therapie op maat.

\section{Bacteriën tegen kanker}

Een compleet andere benadering is het gebruik van bacteriën om medicijnen in zuurstof arme gebieden af te geven. Deze aanpak berust op de eigenschap van zogenaamde anaërobe bacteriën om, alleen in zuurstof arme omgeving te gedijen. Zuurstof remt de deling en verspreiding van deze bacteriën. In samenwerking met de universiteit van Nottingham hebben we in deze bacteriën een enzym ingebracht dat een inactief medicijn - een zogenaamde pro-drug-kan omzetten in een dodelijk medicijn voor kankercellen. Dat betekent wanneer een patiënt met bacteriën en het medicijn worden ingespoten het geneesmiddel alleen werkzaam is in de hypoxische tumor gebieden waar de bacteriën naar toe gaan. In normale weefsels komt de bacterie niet en het medicijn dus ook niet.

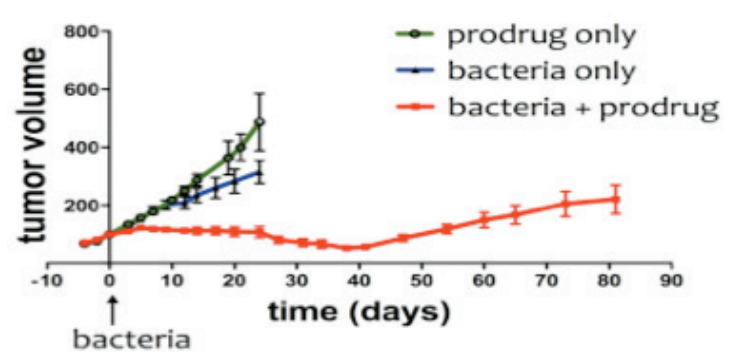

Is dit fictie, nee dit werkt echt. Jan Theys en collega's hebben nu proof of principle geleverd. Muizen die hypoxische tumoren bevatten worden efficiënt gekoloniseerd door deze bacteriën en wanneer de pro-drug ingespoten wordt leidt dat tot vertraging in tumor groei (de rode lijn) (J. Theys et al., unpublished). Dit is een veilige bacterie omdat ze nog steeds gevoelig zijn voor antibiotica en we er dus ook, zo weer vanaf kunnen. Bijna alles ligt klaar voor de eerste test in patiënten; we verwachten in de komende jaren hiermee te beginnen. 


\section{Malaria medicijn doodt resistente kankercel}

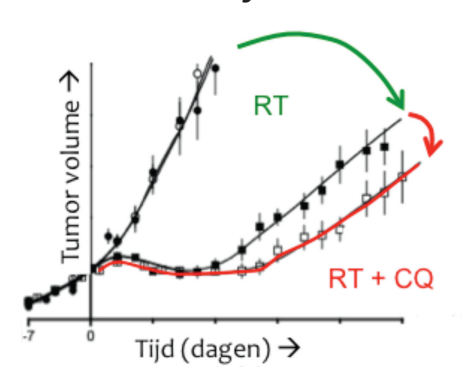

Medicijnen die hypoxische cellen selectief doden zijn interessant omdat dit de meest therapieresistente cellen zijn. In het lab onderzoeken we de processen die betrokken zijn bij overleving van hypoxische tumorcellen. Een van die mechanismen is autofagie, dat letterlijk betekent: zich zelfopeten. Het is soort recyclingproces waarbij gedurende stress zoals zuurstofgebrek, niet essentiële processen in de celhuishouding worden stilgelegd en de bouwstenen van eiwitten hieruit worden vrijgemaakt om nieuwe energie te leveren, een soort noodstroom. Autofagie verhoogt daarmee de overleving van hypoxische kankercellen. Hypoxische cellen kunnen worden gedood met behulp van Chloroquine(CO): een drug die autofagie platlegt. Kasper Rouschop en collega's hebben vastgesteld dat Chloroquine (CO) de therapeutische index verhoogt in hypoxische tumoren door deze tumoren gevoeliger te maken vóór bestraling (de rode pijl)..$^{18}$ Chloroquine is een oud-en-bekend anti-malariamidde dat door basaal onderzoek nu nieuwe kansen heeft; mogelijk als anti-kankermedicijn. Hoewel er voor farmaceutische bedrijven niets meer aan te verdienen is betekent dit niet dat patiënten er niet beter van zouden kunnen worden. Het vinden van nieuwe toepassingen voor oude medicijnen is interessant vanwege de enorme kosten gemoeid met de ontwikkeling en regelgeving rondom de toelating- van nieuwe medicijnen. Bovendien is het verbeteren van een bestaand en geregistreerd geneesmiddel dat matig werkt vaak eenvoudiger en vee sneller dan het vinden van een compleet nieuw medicijn.

\section{Notch remming; twee vliegen in een klap?}

Een van de kankers waar we ons met name op richten is het nietkleincellig longcarcinoom. De vooruitzichten zijn uitermate slecht. 40\% procent overlijdt binnen het eerste jaar na diagnose. Na 10 jaar is $90 \%$ dood. Er is dus veel winst te behalen voor deze patiënten. We richten ons onder andere op de rol van de NOTCH signalering route. Dit is een eiwit op het celoppervlak en belangrijk voor cel-cel communicatie. Dat kan tussen cellen van dezelfde soort zijn maar ook tussen verschillende celtypen. In veel kankers (ook longkanker) is er altijd iets mis met de celcel communicatie en dit heeft dikwijls ook met Notch te maken. Echte hoe precies is verre van duidelijk. Interessant is dat Notch niet alleen belangrijk is in tumorcellen maar ook in tumor-angiogenese. ${ }^{19}$ De cellen met actief NOTCH in een tumor en in de bloedvaten zijn hier blauw gekleurd. Het zal u dan ook niet verbazen dat hypoxie NOTCH activeert. Samen met het VEGF coördineren ze bloedvat vorming. Kankers die resistent zijn geworden tegen remmers van VEGF blijken nog wel gevoelig voor NOTCH remming. Remming van NOTCH in kanker zou dus zowel de bloedvaten als de kankercellen kunnen aanpakken, twee vliegen in een klap.

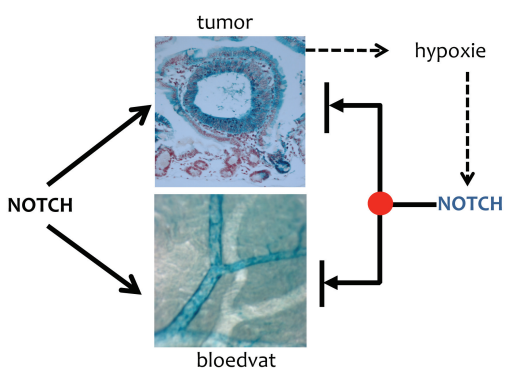

Echter NOTCH heeft ook heel belangrijke functies in normale weefsels. Voor anti-Notch medicatie is dit slecht nieuws we willen normale cellen met rust laten. En, ik had u nog niet verteld dat dit NOTCH eiwit ook nog een broer en twee zussen heeft. Dus nog $4 \mathrm{NOTCH}$ eiwitten die op elkaar lijken, maar ook verschillen. We zijn nu die verschillen in kaart aan het brengen en onderzoeken in welke mate ze betrokken zijn bij longkanker, en of remming kankergroei vertraagt of cellen gevoeliger maakt voor bestraling. Maar misschien ook wel andersom. Uit onderzoek blijkt nu dat als je te weinig Notch hebt dat ook kanker kan veroorzaken, bijvoorbeeld van de bloedvaten maar ook in in het hoofdhals gebied en in long. Dat is misschien minder onverwacht; immers, teveel net als te weinig communicatie is óók storend voor cellen.

Misschien zult u ook denken: maar als je bloedvaten doodt dan krijg je toch weer hypoxie? Klopt. Dat lijkt dus een Catch 22. Wat essentieel wordt is het tijdstip van behandeling. Misschien leidt u uit bovenstaande af dat we juist bloedvaten moeten herstellen, dan komt er meer zuurstof, groeien de kankercellen sneller en zijn ze dus gevoeliger voor chemotherapie en radiotherapie. Dat is géén verkeerde gedachte. Dit zijn vragen waar we het antwoord momenteel niet op hebben en die we gaan onderzoeken. Alleen dan zal de toepassing van Notch medicijnen als anti-kankermiddel een goede kans van slagen hebben. 
Ik wil afsluiten met hoop. Hoewel de tumor-omgeving behandeling in een aantal opzichten compliceert biedt het ook nieuwe aangrijpingspunten, misschien zijn normale cellen wel een deel van de oplossing.

Er heeft nog een andere verandering in denken plaatsgevonden, misschien wel de meest radicale. Namelijk in de beeldvorming die tumorcellen hebben, als onoverwinnelijke tirannen. Misschien doet de hypoxische en therapie-resistente tumorcel zich wel stoerder voor dan hij is? Er zijn steeds meer aanwijzingen dat kankercellen ook een zwakke kant hebben en maar een beperkt aantal reservespelers hebben op de bank. Als we die uitschakelen en vervolgens een goede partij spelen is er hoop. Dit concept is vernieuwend en lijkt te werken bij bepaalde erfelijke borstkankers. ${ }^{20}$ Er zijn aanwijzingen dat het hetzelfde opgaat voor hypoxische cellen. Ik noemde $u$ al het voorbeeld uit ons eigen lab van het blokkeren van autofagie dat dodelijk is voor hypoxische tumorcellen maar normale cellen vrijwel ongemoeid laat. ${ }^{18}$ Ik hoop dat uit bovenstaande duidelijk is dat de afdeling Radiotherapie en Maastro de juiste omgeving is om deze concepten vanuit het lab naar de patiënt te brengen de komende jaren. Ik heb daar in ieder geval vertrouwen in.

Ik hoop u duidelijk gemaakt te hebben dat basaal wetenschappelijk onderzoek de basis vormt voor de nieuwe mogelijkheden voo kankergenezing. Dat tumorheterogeniteit eerder regel is en geen uitzondering; geen twee kankers hetzelfde. Dat moet ook consequenties hebben voor behandeling; effectieve kankertherapie is maatwerk. Door de enorme versnelling in technologieën is het binnen enkele jaren mogelijk voor enkele honderden euro's een compleet beeld te hebben van de genetische veranderingen in je eigen kanker. Deze informatie zal voorspellen welke patiënten, wel en welke niet, op een medicijn zullen reageren. Ik voorzie een sterk toenemende rol voor biologische (functionele) beeldvorming tijdens alle trajecten van de behandeling Behandeling op maat betekent dus ook een betere selectie van patiënten die geen baat zullen hebben bij bepaalde therapieën. Dat betekent kostenbesparing. Omdat radiotherapie nauwkeurig, snel, lokaal en goedkoop is zal dat een belangrijke rol innemen in geïndividualiseerde therapie van de toekomst. Ik heb u getracht een aantal voorbeelden te laten zien uit eigen keuken. Een mooi voorbeeld van de kracht van de Maastro Clinic alliantie met het MUMC+. Echte vertaling van kennis en ontdekking uit het lab naar nieuwe behandeling voor patiënten: bench to bedside.
De individualisering van kankerbehandeling is een feit. De toenemende zorgvraag en de kosten hiermee gemoeid dwingen om bundeling van kwaliteit en efficiëntie. Het multidisciplinaire karakter van de microomgeving in kanker behandeling betekent ook nieuwe dwarsverbanden in onderzoek en zorg. Die zorg en kennis dient geconcentreerd te worden in centra waarin wetenschappelijk onderzoek, opleiding, onderwijs en medische professionals elkaars dagelijks treffen.

Als ziekenhuis en universiteit is Maastricht kleiner dan de rest van de Nederlandse academische ziekenhuizen. Dat betekent dat we niet alles kunnen doen; we moeten ons voordeel halen uit focus, bundeling van kwaliteit dat zal de doelmatigheid vergroten. Het definiëren van Centers of Excellence met een continuüm van uitstekend wetenschappelijk onderzoek, onderwijs, expert care en extramurale zorg is daar een belangrijk instrument in. Uiteindelijk creëert dit ook nieuwe bedrijvigheid en technologie ontwikkeling. Die transitie vraagt om nieuwe organisatiestructuren en financiering. Dat is de taak van de overheid en keuzes binnen de academische centra en van zorgverzekeraars. Een ding verandert niet: goed wetenschappelijk onderzoek vormt de basis van die nieuwe geneeskunde. 


\section{Dankwoord}

Dan wil ik nu afsluiten met een woord van dank. Allereerst wil ik Martin Paul, Jo Ritzen, Frans Ramaekers en Philippe Lambin bedanken die deze leerstoel mogelijk hebben gemaakt. Er zijn veel mensen die richting hebben gegeven en betrokken waren bij de wetenschappelijke vorming, het plezier en succes in het werk. In chronologische volgorde; Joe Gray en Pieter de Jong van het Lawrence Livermore National Laboratories waar ik 11/2 jaar als student biologie stage kon doen in het human genome center en de UCSF campus. Veel dank aan mijn promoter Ton Berns en mijn collega's van het Nederlands Kanker Instituut waar ik, in een enorm stimulerende omgeving, mijn opleiding in wetenschappelijk onderzoek heb gekregen. Many thanks to Raphael Kopan at Washington University in Saint Louis for your mentorschap; you took it serious. You inspired me. Vervolgens in het Hubrecht Instituut bij Hans Clevers. Ik kon mijn onderzoek uit de VS daar verder uitwerken, dank daarvoor. Ook hier was onderzoek doen heel laagdrempelig, een inspirerende omgeving, gedreven puur door wetenschap. Daarna ruim 4 jaar samen met Elsken van der Wall en Paul van Diest op de afdeling Pathologie van het UMC Utrecht. Paul we waren een goed team dat elkaar niet in de weg liep maar versterkte, je leerde me veel over translationeel onderzoek en het werken met mensen. Je gaf me vertrouwen en ruimte mijn eigen dingen verder te ontwikkelen, dat resulteerde in een belangrijke subsidie. Je steunde me ook toen ik besloot te vertrekken, daar ben ik je dankbaar voor Onderzoek doe je samen; dat is ook wat er leuk aan is. In Utrecht heb ik met heel veel plezier gewerkt met Eelke, Karijn, Arjan, Geert, en Cigdem mijn eerste promovendi. Ook met postdocs Theo, lordanka en Petra en de analisten Ingrid en Jan en de vele MSc studenten zij leverden allemaal belangrijke bijdragen. De huidige staf in Maastro lab Ludwig, Kasper, Jan en Philippe een uitstekend team met heel veel potentie die me ruim 2 jaar geleden met open armen hebben opgenomen in -een voo mij- nieuw onderzoeksveld. De huidige promovendi Roger, Sanaz, Marco, Sarah, Barry, Kranthi en Marike en postdocs; Arjan, Alexey, Maud, Twan, Caroline, Chantal, Frank en Ruchi en de analisten Kim S, Kim P, Natasja, Tom en Rianne en Carla die alles snel regelt op het secretariaat, allemaal getalenteerde individuen. Ik kijk er naar uit om samen met jullie en met onze collegae fysici en radiotherapeuten en medewerkers van Maastro Clinic onderzoek te doen de komende jaren. Philippe, bedankt voor de kans om een niet-radiobioloog te kiezen voor de positie hoofd van het radiotherapie lab. Het is een voorbeeld van je vermogen om open staan voor vernieuwing en het nemen van risico, wat ik erg in je waardeer als onderzoeker. Het is een belangrijke reden van het internationale succes van Maastro Clinic. Je gedrevenheid inspireert het vakgebied; je bent continue op zoek naar vernieuwing en verbetering in onderzoek en onderwijs. Het basale en translationele onderzoek in ons laboratorium is ondermeer gefinancierd door nationale en internationale publieke en private fondsen zoals KWF Kankerbestrijding, NWO en de Europese Unie. Tenslotte mijn ouders, papa en mama, jullie vormden de basis. Jullie hebben altijd achter me gestaan in mij geloofd. Heel veel ruimte en mogelijkheden gegeven, me nooit een richting ingeduwd maar mijn eigen weg laten gaan / laten zoeken, dat is zo belangrijk.

Mascha en mijn kinderen, Aurelle, Romeyn en Timmin. Alles wat ik hier schrijf doet tekort aan hoe belangrijk jullie zijn elke dag opnieuw in mijn leven.

Ik heb gezegd,

Marc Vooijs 


\section{Geraadpleegde literatuur}

1. van KWF Kankerbestrijding, S. K. Kanker in Nederland tot 2020 Trends en prognoses. 1-280 (Vereniging van Integrale Kankercentra: 2011).

2. Boveri, T. Zur frage der entstehung maligner tumoren (Jena: Gustav Fischer) (English translation). (The Origin of Malignant Tumors: 1914).

3. Hanahan, D. \& Weinberg, R. A. The hallmarks of cancer. Cell 100, 57-70 (2000).

4. Stratton, M. R., Campbell, P. J. \& Futreal, P. A. The cancer genome. Nature 458, 719-724 (2009).

5. Paget, S. The distribution of secondary growth in cancer of breast. Lancet 1 571-573 (1889).

6. Hanahan, D. \& Coussens, L. M. Accessories to the Crime: Functions of Cells Recruited to the Tumor Microenvironment. Cancer Cell 21, 309-322 (2012).

7. Hanahan, D. \& Weinberg, R. A. Hallmarks of cancer: the next generation. Cell 144, 646-674 (2011).

8. Konerding, M. A. Blood Perfusion and Microenvironment of Human Tumors. (Springer Verlag: 2000).

9. Gort, E. H., Groot, A. J., van der Wall, E., van Diest, P. J. \& Vooijs, M. Hypoxic regulation of metastasis via hypoxia-inducible factors. Curr Mol Med $\mathbf{8}$, 6o-67 (2008)

10. Höckel, M., Schlenger, K., Knoop, C. \& Vaupel, P. Oxygenation of carcinomas of the uterine cervix: evaluation by computerized $\mathrm{O}_{2}$ tension measurements. Cancer Res 51, 6098 (1991).

11. Bos, R. et al. Levels of hypoxia-inducible factor-1 alpha during breast carcinogenesis. J Natl Cancer Inst 93, 309-314 (2001).

12. Höckel, M. \& Vaupel, P. Prognostic Significance of Tissue Hypoxia Incervical Cancer. Journal of Gynecologic Oncology 6, 216-225 (2001).

13. Brown, J. M. Exploiting the hypoxic cancer cell: mechanisms and therapeutic strategies. Mol Med Today 6, 157-162 (2000).

14. Janssens, G. O. et al. Accelerated Radiotherapy With Carbogen and Nicotinamide for Laryngeal Cancer: Results of a Phase III Randomized Trial. J Clin Oncol 30, 1777-1783 (2012).
15. Overgaard, J. et al. A randomized double-blind phase III study of nimorazole as a hypoxic radiosensitizer of primary radiotherapy in supraglottic larynx and pharynx carcinoma. Results of the Danish Head and Neck Cancer Study (DAHANCA) Protocol 5-85. Radiotherapy and Oncology 46, 135-146 (1998).

16. Dubois, L. et al., Preclinical evaluation and validation of [18F] HX4, a promising hypoxia marker for PET imaging. Proceedings National Academy of Sciences USA 108, 14620-25 (2011).

17. van Loon, J. et al. PET imaging of hypoxia using [18F]HX4: a phase trial. Eur. J. Nucl. Med. Mol. Imaging 37, 1663-1668 (2010).

18. Rouschop, K. M. A. et al. The unfolded protein response protects human tumor cells during hypoxia through regulation of the autophagy genes MAP1LC3B and ATG5. J Clin Invest 120, 127-141 (2010).

9. Vooijs, M. et al. Mapping the consequence of Notch1 proteolysis in vivo with NIP-CRE. Development 134, 535-544 (2007).

20. Rehman, F. L., Lord, C. J. \& Ashworth, A. Synthetic lethal approaches to breast cancer therapy. Nature reviews. Clinical oncology 7, 718-724 (2010). 